\title{
Museum education, cultural sustainability, and English language teaching in Spain
}

\section{Luis S. Villacañas de Castro, Laura M. Moreno-Serrano \& Clàudia Giner Real}

To cite this article: Luis S. Villacañas de Castro, Laura M. Moreno-Serrano \& Clàudia Giner Real (2022) Museum education, cultural sustainability, and English language teaching in Spain, Pedagogy, Culture \& Society, 30:2, 201-223, DOI: 10.1080/14681366.2020.1794947

To link to this article: https://doi.org/10.1080/14681366.2020.1794947

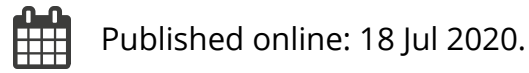

Submit your article to this journal $₫$

山ll Article views: 295

Q View related articles $\asymp$

View Crossmark data 


\title{
Museum education, cultural sustainability, and English language teaching in Spain
}

\author{
Luis S. Villacañas de Castro (D) ${ }^{\mathrm{a}}$, Laura M. Moreno-Serrano iD $^{\mathrm{b}}$ and Clàudia Giner Real ${ }^{\mathrm{c}}$
}

aDepartment of Language and Literature Education, Facultat de Magisteri, Universitat de València, València, Spain; 'bepartment of English and German, Facultat de Filologia, Traducció i Comunicació, Universitat de València, València, Spain; 'Facultat de Magisteri, Universitat de València, València, Spain

\begin{abstract}
The collaborative action research project presented analysed the potential of museum education to radically transform the way in which English was taught and learnt in three diverse elementary, middle, and high-school contexts in the province of València (Spain). Insights from museum education and New Literacy Studies were used to expand upon the pedagogical affordances of the material and multimodal dimensions of English language teaching, in order to generate more opportunities for student motivation and engagement by connecting with the learners' home and community cultures, identities, languages, and literacies. To assess the impact of the project, a variety of qualitative strategies were used (including classroom recordings, student interviews and questionnaires, and photographs). A model for culturally sustaining pedagogy was suggested, which school and museum educators may use to inform their practice.
\end{abstract}

\section{KEYWORDS}

English language teaching; museum education; new

Literacy Studies; artefacts; culturally sustaining pedagogy

\section{Introduction}

Museum education is not a frequent source of pedagogical inspiration for English language teaching (ELT). Apart from indirect suggestions about museums and exhibitions containing authentic English labels that learners could benefit from, ELT has shown little or no interest in understanding how museums work as educational sites that engage (or fail to engage) visitors in meaningful learning situations. Although there are exceptions (García-Sampedro 2019), the field has not often asked itself what English language teachers can learn from museums to design appealing curricula for their subject. Nevertheless, recent developments in ELT connected to multimodality (Burke and Hardware 2015; Early, Kendrick, and Potts 2015) and to a more profound interpretation of the material dimensions of literacy (Pahl and Rowsell 2010; Thiel 2015; Villacañas de Castro et al. 2020) have set the conditions for the intersection of museum education and ELT to sound both reasonable and timely. This is precisely what this article sustains. Through theoretical and empirical sections, it will contend that museum education includes concepts and practices which are valuable for English teachers who wish for

CONTACT Luis S. Villacañas de Castro Luis.villacanas@uv.es Department of Language and Literature Education, Facultat de Magisteri, Universitat de València, València 46022, Spain 
their lessons to develop directly on a culturally-sustaining plane (Paris and Alim 2014), and thus to become more interesting for all learners (Porto 2010).

The following section presents a brief account of the theoretical contours of museum education in search of its own pedagogy and for a more prominent role in ELT curriculum design and development. Then, through three educational vignettes conducted in socially diverse educational contexts in Spain, the article will illustrate how museum pedagogy can become a fruitful ally of all those English language teachers who wish to include the students' multiple cultures, modalities, literacies, and languages in the learning process. While English learners (especially those coming from non-privileged contexts) find it increasingly difficult to relate their lives, experiences, and cultural capitals to the English language (Villacañas de Castro, Bodi Cano, and Hortelano Montejano 2018; Block 2012; Kanno 2014; Vandrick 2014), museum pedagogy may provide English teachers with a powerful tool to overcome this obstacle.

\section{Museum education and cultural sustainability}

Factors deeply ingrained in museum institutional history and in the status of its educators (Eisner and Dobbs 1986) account for the fact that, while these institutions bear immense potential as 'key sites for learning' and display great 'pedagogical power' (HooperGreenhill 2007, 201), on very few occasions have they fulfilled their educative promise. According to Kristinsdóttir (2017), museums often run in the absence of any educational theory, and Hooper-Greenhill (1999) and Christensen-Scheel (2017) have claimed that museum education is still in search of its most adequate pedagogy. Interestingly, in many ways these analyses of museum education mirror problems still found in schools and in the rest of institutions of formal education. For example, just as there are traditional communication theories, and hence also traditional (and behaviourist) learning theories based on them, traditional approaches to museum education have tended to rely on content transmission and silent tours rather than on encouraging the audience to creatively interact with the artefacts and displays, or to participate in planning the exhibition from the outset, as would be expected from constructivist and participatory pedagogical perspectives (Hein 2011; Martin and Jennings 2015).

A parallel development of this traditional approach can be seen in how museums have diminished the educational dimension of the institution to privilege its role as a cultural deposit (Costantino 2004), even when, as pointed out by Huerta (2010, 39), 'an important sector of visitors to museums depend on what school and high school teachers decide'. According to Eisner and Dobbs (1988, 10-11), this is the reason why museums are 'culturally rich and pedagogically poor' (cited in Kristinsdóttir 2017, 428). In addition, an elitist, monolithic view of Culture (with a capital C) (Moirano 2012), as opposed to a multicultural one that welcomes minority cultures and life perspectives, has often accompanied these educational approaches. This elitist view of culture ends up manifesting itself in the semiotic choices that curators or exhibition designers make, ones through which the cultural and educative nature of museums are often narrowed to conform only to small and privileged social groups. For example, in their exhaustive account of the process of institutional transformation that the Children's Discovery Museum of San Jose underwent to attract and engage ethnic minorities, Martin and Jennings (2015) reported how, before the mentioned steps were taken, the Latin and Vietnamese communities 
were dramatically underrepresented as museum visitors. The reality of this disparity in who attends and actually learns from museums betrays how these institutions are failing to fulfill their democratic aims.

Unsurprisingly, the same kind of cultural profiling has been noted in all institutions of formal education (Delpit 2006; Sayer 2019), whose curricula often privilege certain forms of cultural capital while others are pathologized and denied the possibility of receiving educational appreciation. 'Like schools,' wrote Hooper-Greenhill (1999, 22), 'museums too claim to be for everyone, but both the visitor statistics and the research studies ... insist that museums are not experienced equally by all'. However, efforts have been made to render museums more accessible to a wider audience and, ultimately, to democratise culture and knowledge through experimental and affective involvement. The new museology movement, during the nineteen seventies, or the so-called educational turn in art, during the nineties - which conceptualised art as an interactive experience through which the audience built connections between their own life experiences and the epistemic and social knowledge embedded in artefacts (Christensen-Scheel 2017; Stojanovic 2017) - both presented important challenges to traditional pedagogical understandings in museum education. Finally, at present certain museums are reformulating their missions in terms of cultural sustainability (Kristinsdóttir 2017), a concept that is also being used by those educators who, through their own culturally sustaining pedagogies, 'seek to perpetuate and foster - to sustain - linguistic, literate, and cultural pluralism as part of schooling for positive social transformation' (Alim and Paris 2017, 1). Questioning the traditional understandings of language, literacy, and culture is instrumental to this aim.

Indeed, research on the multimodal and material aspects of literacy has contributed to the empirical concretion of culture, to the understanding of their interrelated nature, and to how they could be organised and utilised in actual educational settings (Pahl and Rowsell 2012). There is evidence that, whenever individuals' educational experiences are limiting and impoverishing - something that is frequent in English language teaching - the problem tends to lie not only in the general (and narrow) views of culture that are held in them, but also in the way different literacies, modalities, and languages are organised in schools and museums, since it is through them that culture and identity are actually constructed, reconstructed, and performed. For instance, as the staff of the Children's Discovery Museum of San Jose (California) tried to improve their cultural competence and reach out to local Latin American and Vietnamese cultural minorities, they soon discovered the need, not only to incorporate Spanish and Vietnamese texts in multilingual exhibitions and resources, but also to make sure that these texts were adapted to the culturally- and dialectically-inflected language forms and literacies used by San José residents (Martin and Jennings 2015, 86). This was a critical step towards understanding that 'culture is much broader than ethnicity' (92) and also towards the professional realisation that the transformation envisioned by the museum staff had to be global in scope and encompass a large variety of factors.

Lack of due attention to the pedagogical impact of culture, multimodality, multiliteracy, and multilingualism may even come to endanger the basic educational power of artefacts, which are museum's key resources. As Jarmy $(2019,434-5)$ put it, it is 'through space, light, resources, and the selection and juxtaposition of artifacts [that] a clearing is carved out that enables us to see an artifact in a certain way ... as things with a rich web of reflections, which are brought out in the museum.' Yet even the culmination of this process, and thus the satisfaction of one essential aim of museums, demands a certain 
degree of pedagogical knowledge in relation to the material, artifactual, and multimodal qualities of these institutions. Very often artefacts are still displayed according to what Yun $(2018,274)$ called the 'curatorial and pedagogical default method,' which remains fixated on chronologically focused depictions of history, at the expense of presenting audiences with fully-contextualised and embodied learning experiences. In the same manner, traditional exhibitions also curtail the communicative and educational potential of their artifactual resources by privileging elitist representations of culture by reinforcing academic literacies and its printed modes. Ansbacher $(1998,47)$, for example, claimed that museums 'tend to rely on labels carrying the messages they wish to communicate, in the worst cases not even relating well to the objects or phenomena on display', and Huerta (2010) analysed the 2001 Tate Britain reforms in similar terms. Instead of designing more open, flexible, and democratic relations between the verbal and nonverbal dimensions, between the printed and non-printed modalities, and between the academic and nonacademic literacies of the exhibitions, museums seem to comply to a double hierarchy that subdues, first, the visual and artifactual modalities to the printed mode, which are then qualified in favour of academic literacies and against informal ones (Davidson, Heald, and Hein 2008). In this way artefacts are eclipsed by words, which in turn bend towards socially-, culturally-, and ethnically privileged discourses.

\section{New literacies and museum education}

Perhaps not surprisingly, Hooper-Greenhill (1999) argued that for museums to succeed in engaging multiple audiences in genuine educational experiences, curators, exhibition designers, museum educators, and the rest of museum professionals need to interpret the choices they make in terms of societal power. This critical orientation also lies at the heart of culturally sustaining pedagogies. According to Hooper-Greenhill, 'some museums are already finding ways to democratize their working practices ... they are introducing multiple perspectives that give sub-groups and difference a voice' (23). Her use of the term 'voice' (at some point she also speaks of 'narratives') suggests that the same idea may apply to ELT, a field whose actual learning outcomes are also influenced by socioeconomic and cultural factors (Vandrick 2014). Despite the intrinsic value that liberal education attributes to learning a foreign language - Williams (2020) emphasised the 'playful quality,' 'textual pleasure,' and the 'delight in the literal conversations conducted in different languages' (547) - the field of ELT is increasingly shaped by neoliberal socioeconomic and socio-cultural inertias. 'It is generally the upper and middle classes of countries around the world who are successful learners of English', summarised Block $(2012,202)$. Accordingly, one of the most interesting critical developments in ELT today has to do with how theories of multimodality and multiple literacies are enabling further democratisation of English education across cultural, linguistic, ethnic, and socioeconomic lines (Giampapa 2010; Kennedy, Oviatt, and De Costa 2019). Premised on socioconstructivist and critical orientations, New Literacy Studies (NLS) addressed literacy as a social practice imbedded in students' everyday lives and influenced by their material and cultural surroundings (Gee 2014). By opening itself to these understandings and translating them into its own theoretical and practical concepts, the field of ELT may learn how to sustain and capitalise on the students' original cultures and identities in the English classroom by widening the range of modalities, literacies, and languages included 
in it (Street 2012). As will be discussed in the experimental sections of this article, photographs, drawings, family possessions, and household, neighbourhood and community objects may be invited to the English classroom, together with the competences and literacies that the students experience, interact with, and utilise on a daily basis.

Multimodal and artifactual approaches to literacy clearly insist on some of the affordances that the field of ELT has traditionally found in visuals and realia (Gobert 2018). However, by articulating the latter into the wider and richer social understanding provided by NLS we believe that ELT can amplify and intensify the pedagogical potential currently assigned to these resources. To that extent, NLS may also pave the way for ELT to establish fresh links with museum education and take full advantage of its multimodal pedagogies, especially as far as multiculturalism is concerned. At the end of the day, the same factors that make an exhibition successful can also contribute to making English education meaningful for all learners, regardless of their socio-economic and cultural backgrounds - far from being the case as is. Apart from Martin and Jennings' (2015) case study of the Children's Discovery Museum of San Jose, described above, Pahl and Pollard (2010) showed how literacy development, multiculturalism, and museum education may reciprocally enrich one another. At the heart of their artistic and educational experience (Pahl is a prominent new literacies scholar; Pollard, a professional curator) was an exhibition at a local museum in South Yorkshire (United Kingdom) that displayed household objects coming from neighbourhood families of Pakistani heritage. The exhibit also registered and included the stories attached to each of those artefacts (what made them special and meaningful for the families who owned them) which the authors retrieved through ethnographic interviews. The families' cultures and stories were thus allowed to shine through their own objects, texts, and words. Cummins and Early (2010) model of identity texts also emphasised, in a similar manner, the need for teachers to find real audiences for their students to share their school work with, since the students' learner identity and self-concept improved significantly when this happened.

\section{School museums}

Cummins and Early (2010), Pahl and Pollard (2010), and Martin and Jennings' (2015) work lead us on the way to appreciating the contributions that museum education can make to English language classrooms. Until now this article has mostly focused on some of the negative dynamics that shape both museums and schools, but its main interest lies in strengthening positive transfers and reciprocal enrichments between these two educational institutions. On this regard, Dewey, one of the first pedagogues to favour museums' educational function over their role as cultural preserves or deposits (Costantino 2004), already insisted that schools organise continuous visits to nearby museums for teachers to better contextualise their teaching with examples taken from past history and real social life (Hein 2004). Apart from this recommendation, Dewey (1915) also suggested that every school develop its own museum to fulfill a double educational function. First, it would give the students a final chance to reflect, 'organize and analyze the results of [the educational] experience' conducted within any given subject (Hein 2004, 420). Indeed, educational initiatives as sophisticated as those Dewey described in his works - which included language and artefacts, signs and tools, educational as much as social rationalities - would require nothing less than an entire exhibition to systematise its process and aims. Secondly, 


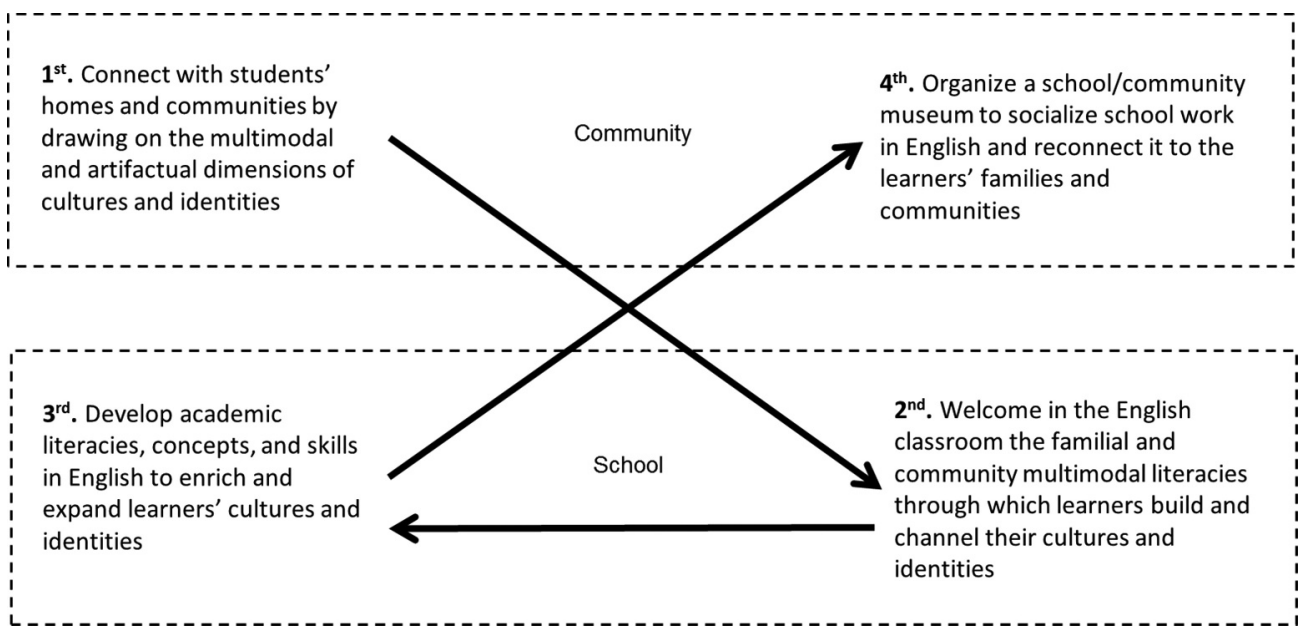

Figure 1. School museums and the interplay between the school and the community.

and in addition to this meta-pedagogical reflection, school museums would also help students and teachers to share their work and assess it according to criteria other than those normally used in academic assignments.

Following from Dewey (1915), Figure 1 shows how school museums would close the circle of education in the following way: At the starting point of the academic process, the school would sustain the students' original and local cultures, identities, modalities, and literacies, by welcoming them in multimodal and artifactual ways and basing English education on them. In the last phase, by contrast, the school museum would turn itself into physical third space (Wilson 2004) between school and society, one through which the school would give back to the community those local cultures, identities, literacies, and languages that the students deposited at the beginning, albeit transformed and enriched through the different academic skills and literacies developed at school. In the case of ELT, parents, neighbours, community leaders, etc., would approach the school museum and appreciate the children's English outcomes not through strict academic lenses but as general contributions to their communities. Through these four phases, schools could draw on the multimodal and artifactual qualities of museum education to create an educational environment that satisfies the basic tenets of cultural sustaining pedagogies, as well as one of the founding principles of museums: namely, the fact that 'learning is essentially a public event' (Yun 2018). As we have seen, the artifactual nature of museums is instrumental for learning to be 'generated or experienced at the community level in this very materialized form' (480).

\section{Methodological and analytical frameworks}

The four phases described in Figure 1 are present in the three vignettes through which this article presents the affordances of museum education to transform English language teaching according to a model of culturally sustaining pedagogy. Figure 2 illustrates this model, which relies on the interconnected natures of culture, modality, literacy, and language. In accordance with the insights of NLS, the model claims that, for education 


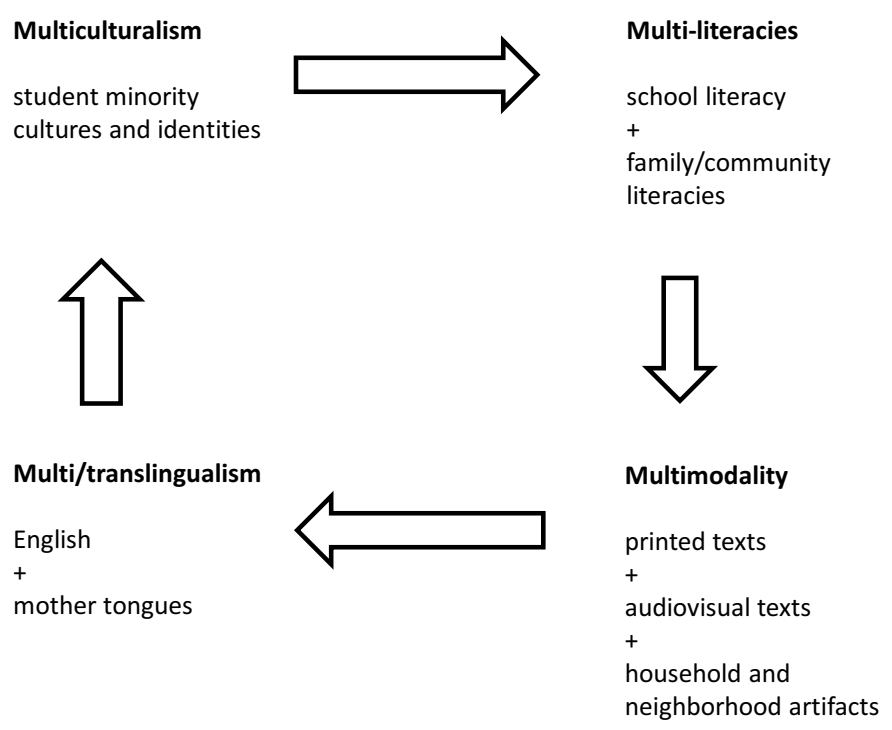

Figure 2. A model of culturally sustaining pedagogy (Villacañas de Castro et al. 2020).

to be multicultural, it first has to welcome the multiple literacies through which learners' cultures are originally built and conveyed; this, in turn, demands that the educational context be multimodal and artifactual (because home or community literacies clearly support themselves on multiple modalities and artefacts), which, likewise, requires that the languages through which each of these literacies were originally built be accepted and assimilated into the educative context, be it a museum or a language classroom (Villacañas de Castro et al. 2020).

This was the model the authors put into practice during the 2017-2018 school year in very diverse educational settings in the province of València (Spain). The first vignette describes an interdisciplinary museum project organised in a charter medium school in the forests surrounding Picassent, a town in the province of València. The second vignette focuses on the creation of a high school museum that linked the English language to the youth cultures and identities that teenagers developed around music in a working-class neighbourhood in València's metropolitan area. And finally, the third example describes and analyzes the process and outcomes of a community museum set in a public primary school in Nazaret, one of the most impoverished neighbourhoods in the capital city of València. Not only were these contexts different, but their initiatives were developed under different circumstances as well. The first two unfolded during the three-month practicum placement periods that Laura and Clàudia completed as part of the Master's Degree in English Language Teaching in Secondary Education they were studying. Luis acted as their university supervisor while he also developed his own ELT museum at the abovementioned school in Nazaret.

Despite these diverse contexts, Laura, Clàudia, and Luis were interested in exploring how museum education could maximise the multimodal and artifactual dimensions of English language teaching and learning, and also how these two dimensions, when strengthened through museum-oriented pedagogies, could result in higher student motivation and engagement by connecting and better channelling their cultures, identities, and 
corresponding literacies into the English classroom. With this common research goal in mind, Laura, Clàudia, and Luis became teachers as researchers (Stenhouse 1975), as they were interested in reflecting on the educational value of their ELT curricular proposals (Graves 2008). Consequently, they agreed on setting a collaborative action research network (Banegas et al. 2013; Burns 2005) to share and assess the processes and outcomes of their museum projects. Laura wished to move up the university ladder, Clàudia longed to become a school teacher, while Luis had already established himself as a university lecturer and researcher. Still, despite this diversity of career goals and interests, all three agreed that action research would allow them to improve their understanding of what went on inside a diversity of ELT school contexts, yet without interfering with the deontological ethics of teaching or with the internal ecologies of classroom learning. This certainty made their collaborative effort possible. Accordingly, data were analysed within a qualitative research paradigm whose methods respected the school cultures found in each of the institutions they accessed. They drew on individual and group interviews with students and/or school teachers, sound recordings from key school sessions, analysis of the students' work (i.e., of the outcomes that were displayed in the exhibitions, of the work completed during the intermediate phases, etc.), and also their journals. Photographs were also taken at significant moments during the project. Not all projects drew upon all these sources of data, however. When necessary, the authors requested explicit written consent from each of the families to reproduce this evidence, which was granted in all cases. Parents and licenced tutors proudly encouraged their children's work to be publicised for research purposes, so real student names have been used.

Inductive analysis of the data focused on whether the multimodal, artifactual, and linguistic dimensions that were necessarily involved in the creation of these school museums had developed on a culturally sustaining plane, i.e., whether they had enabled the authors to establish stronger links between the English subject and the students' cultures, communities, and identities, and - in turn - whether this had resulted in more meaningful learning experiences for those students involved in the research project. The authors first examined the collected data to filter out the information that was not related in any way to the research question and which would, therefore, not enter the transcription process that they also undertook. The next step in the analysis involved sharing all the transcripts, photographs, and student work, and separately conducting an initial coding. Laura and Clàudia did this work in the process of writing their Master's Final Project, which Luis also supervised. Quotes from the transcripts were then organised thematically using a Microsoft Excel spreadsheet that was collectively revised and filled in. Subsequently, the authors extended the coding process through face-to-face assessment sessions through which they reached inter-coder agreement also a common understanding of the underlying processes that had taken place. Codes like 'youth cultures,' 'multimodal texts,' 'home literacies,' or 'academic identities' proved to be recurrent, as well as categories through which these phenomena became qualified socially and culturally. The most significant evidence and predominant interpretations of the data were thus agreed upon. These provide the backbone of the three vignettes that follow. 


\section{Findings: three vignettes}

\section{The 'natural disasters' project: museum education, English, and academic skills}

Laura organised a school museum during her practicum placement at a charter medium school attended mostly by middle and upper-class learners coming from privileged families. Her curricular proposal combined language and content learning, revolved around the topic of natural disasters, and involved the collaboration of teachers from the English and Natural Sciences departments. She worked with 29 twelve and thirteen year-old students, divided into multi-levelled groups containing five or six learners, who in turn had to choose a specific natural disaster for their research and ensuing museum display. They drew from a variety of platforms and resources (the internet, their course book, and other books from their school library) to look for information about volcanoes, oil spills, nuclear leaks, forest fires, floods, earthquakes, and droughts. From these, they created explanatory PowerPoint presentations in English to organise the information they had gathered and finally shared these with the rest of the class. They simultaneously produced material artefacts that modelled the natural phenomena described.

The participants had the opportunity to systematise and share all of this work in the Natural Sciences Museum of the city of València, a public institution that often lends its premises to schools, as it did in this case. These privileged students were used to rich curricula and project work that reinforced their academic identities, but it was the opportunity to actually share their work in English with an audience and in a prestigious cultural institution that turned this experience into a purposeful, memorable event. Before this, a professional museum educator had visited the classroom to explain the many steps involved in mounting an exhibition. As regards the research aims, during the preparatory phases of the museum project the material artefacts gave the students the chance to translate the concepts into sensory, three-dimensional artefacts for the exhibition (as seen in Figure 3) and also to align the content with their own interests and realities. For example, one of the groups, whose members enjoyed drama, decided to support their academic explanations on hurricanes with a play in English. Similarly, the group that researched 'Forest Fires' went on an excursion to the school's natural surroundings: Dressed as litter pickers, they helped clean the forest to prevent fires and included these photographs in their presentations. Finally, during these initial stages, multimodality also provided effective scaffolding to academic language. As Laura observed in her research journal, while some students were worried that their English proficiency might not be enough to master the academic concepts, the potential of multimodality to contextualise language made them 'feel comfortable with the content while doing something they were familiar with' (Laura's journal, 22 Friday 2018).

In their interviews, the students underscored how demanding, but also rewarding, the project had been from an academic perspective. In accordance with the four phases included in Figure 1 and also with Pahl and Pollard (2010), Martin and Jennings (2015), and Cummins and Early (2010) noted benefits of sharing identity texts, the students' academic identities were boosted as they proved capable of socialising their schoolwork with regular visitors of the Natural Sciences Museum. In doing so, they intensified the value of their work as much as they expanded the range and breadth of their own student identities to encompass civic and 


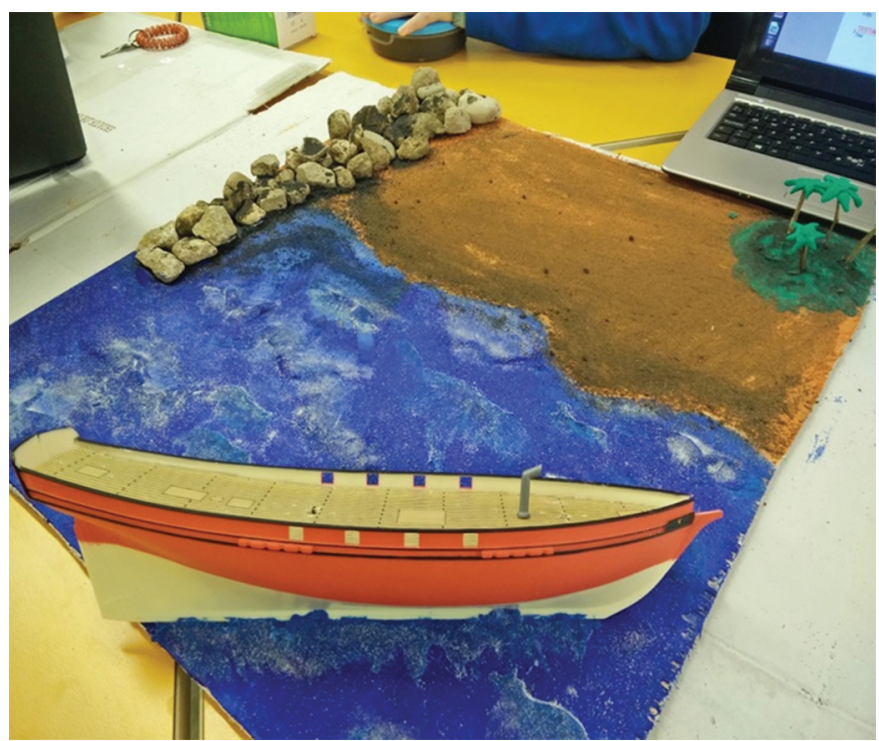

Figure 3. Multimodal and artifactual resources of the 'natural disasters' exhibition.

activist dimensions. 'When you and our teachers asked us about showing our final artifacts,' explained Marcos, 'we were like ... "it's okay, but there is nothing special about it." But when you told us that we were going to show them in the museum, then I really liked the idea, because we had never done anything like that before!' (Marcos, Student interview, 2 March 2018). In line with this impression, Teresa - the in-service teacher and Laura's high school supervisor - underlined the following: 'Have you seen Anna and Carles?! They hardly wanted to speak in English before, yet they felt so confident in the museum!' (Teresa, Teacher interview, 2 March 2018). During the exhibition, student explanations addressed an audience composed of schoolmates from other grades, family members, and regular museum visitors. Learners used the artefacts they had created as supporting evidence and multimodal materials for conveying their scientific explanations. As they worked towards this final display, the design and creation of cardboard volcanoes, maps, riverbeds, etc., not only deepened the understanding of the concepts involved through the research phases but, in addition, facilitated the mastery of the academic vocabulary in English which they required in order to clearly communicate their explanations to their audience. As a visiting Dutch family said, it was a unique and enriching experience:

Visitor 1: [...] I think they made a good presentation and a lot of work to make it. We think that ...

Visitor 2: And it really takes guts to do this in a real situation. It's an example for foreign people, and I think it was very special for them. For a lot of them.

Visitor 1: Yes, people coming from England and listening to their stories; I think it's very special for them. For all of them.

Laura: Yeah, they are having a very good time, I can tell.

Visitor 2: Yes, and they are very young! 
Laura: Twelve years old, some of them thirteen.

Visitor 2: It's a good ... how do you say ervaring?

Visitor 1: Experience! (Interview to museum visitors, 2 March 2018)

Figure 4 shows how the learners' presentations moved to and from the texts, images, diagrams, and artefacts, drawing on all these planes to create meaning. This way the multimodal and artifactual nature of the museum contributed not only to the enriched socialisation of their work but also to the students' attainment of the academic and linguistic goals of the Natural Sciences and English subjects, precisely by supporting and contextualising their written and spoken language.

\section{A 'music and identity museum' in ELT: museum education, youth culture, and identity}

In contrast with 'The Natural Disasters' project, Clàudia organised her 'Music and Identity Museum' in a public high school of Burjassot, a working-class town on the outskirts of València's metropolitan area. A musician herself, Clàudia implemented this curricular proposal in an English classroom of 13 fifteen and sixteen-year-old students who based their museum on how music shaped their youth cultures and identities. This project drew closely on Pahl and Rowsell (2010) artifactual literacies model and Esteban-Guitart and Llopart (2019) funds of identity paradigm, which approaches identity from a socioconstructivist perspective as the internalisation of a variety of socio-cultural artefacts. On this occasion, the main challenge was not so much to better connect the English language to certain academic contents and skills - as was partially the case with Laura's project - but rather to draw on museum pedagogies to channel the learners' youth cultures and identities into the English classroom and make English more meaningful and appealing to these working-class students.

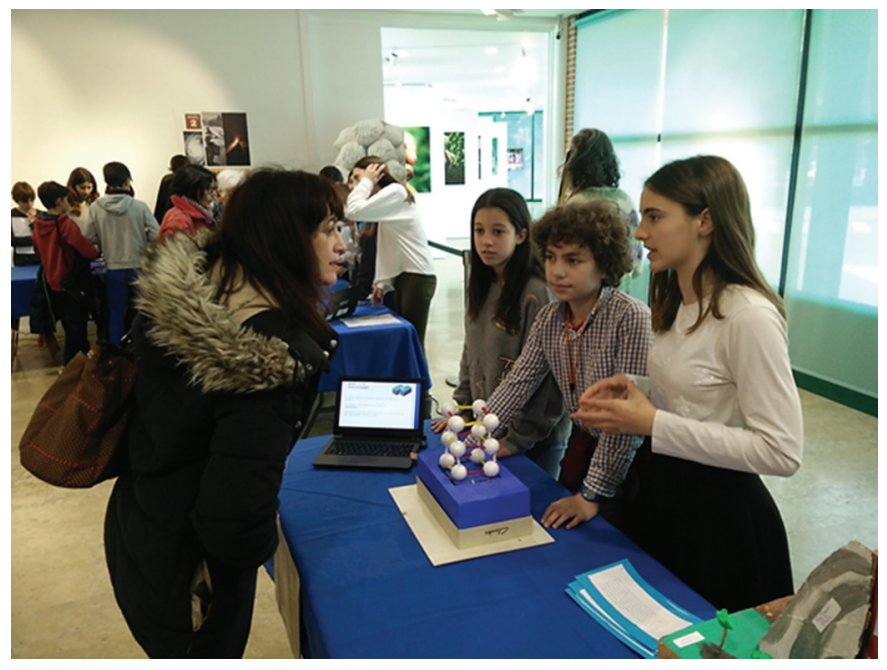

Figure 4. Exhibition at the natural sciences museum. 
To develop our culturally sustaining pedagogical model, in the initial phases of the project the learners brought significant artefacts from home that were related in any way to the world of music, such as compact discs, concert tickets, photographs of their favourite bands, or their own instruments and musical scores, since quite a few were musicians themselves. The students briefly explained these objects orally to the rest of the class (normally using both Spanish and English) and then wrote individual texts in English to summarise the personal story that lay behind them, which reflected why their specific object played a significant role in their personal sense of identity. The texts fell within three main categories depending on the qualities of the artefacts chosen. They either focused on song lyrics, on the image of a favourite band or singer, or on the students' emotions and feelings towards music - as with the last time they had attended a concert, played music with their band, or listened to a special song that brought home a given memory, etc. In the last phase of the museum project (which was carried out in groups) the students took advantage of the artistic affordances of multimodality and matter to organise the artefacts and the corresponding texts for their school museum. Group 3, for example, hung their texts and objects with threads, clothes pegs, and tacks on a corkboard, while Group 1 built a lateral stairway with boxes and stuck the artifactual and multimodal assemblages on them (see Figure 5). The texts, visuals, and objects combined playfully and aesthetically. Unlike Laura's project, the final exhibition was installed in the high school hall for all the students and teachers to discover and learn about the groups' musical identities.

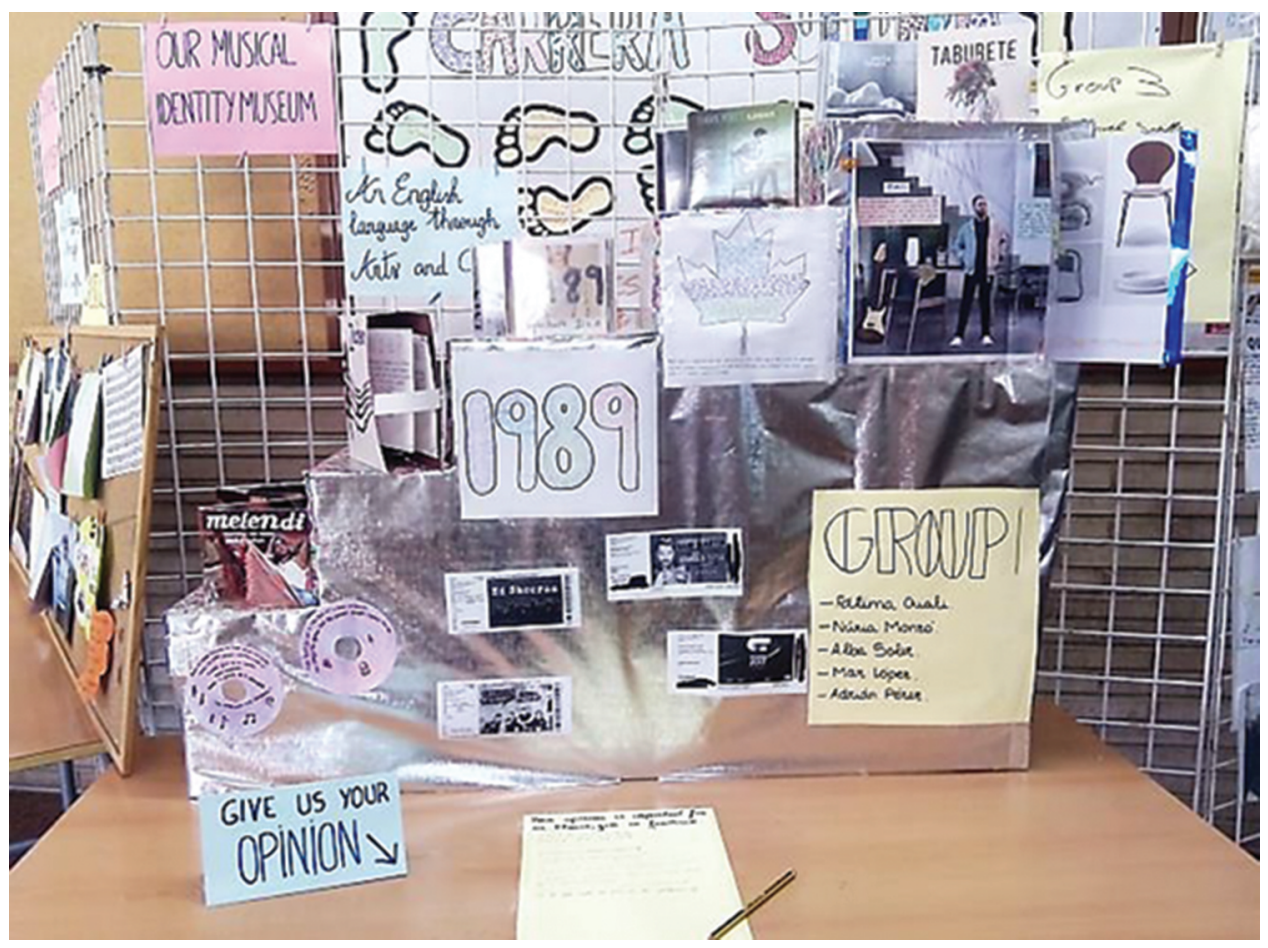

Figure 5. Group display of the 'music and identity museum'. 
First of all, student interviews and questionnaires revealed that, pedagogically speaking, music had been an ideal point of departure for the project to bring the teenagers' cultures and identities on board. Music was possibly the only fund of identity capable of connecting these 13 students to the English language and among themselves, thus creating a genuine classroom community. In her questionnaire, Victoria stated that she had really liked the museum project because, 'apart from reading things and writing, it was about music, which I love' (Victoria, Student questionnaire, 28 March 2018). Saúl added that what he had enjoyed 'above all else [was] the act of describing my favourite artist' (Saúl, Student questionnaire, 28 March 2018). On her part, the English teacher also insisted on the pedagogical potential of music at the end of the project: 'When you ask anyone about the use of English, they answer that [the only use is] to go to England. But no, in this case, they [the students] needed English to express something useful in this context. English was something that was useful for them to express something they liked a lot, such as music' (Teacher interview, 26 March 2018). This piece of evidence suggests that, in keeping with Williams $(2019,2020)$ emphasis on the intrinsic qualities of foreign language learning, the project avoided the danger of becoming significant only for those students whose families could afford visits to English-speaking countries (Block 2012).

Apart from affording a suitable topic to connect with their teenage cultures and identities, music enabled a meaningful use of English in the classroom, since English was the language that dominated the mainstream musical industry. This was an important aspect. Listening to music in English outside school was one of the few cases in which these student lives and the English language meaningfully intersected. Indeed, the students were much more open to listening to music in English, by bands like Tom Walker or Queen (whose lyrics some groups reproduced and translated in their displays), than they were to reading literature in the language. 'For me, music means get away of reality [sic], where it's all cool and happiness,' wrote María about the lyrics of a famous song by Queen. As shown in Figure 6, the project allowed them to reflect on the songs' explicit or implicit messages.

In addition, this curricular proposal welcomed the multimodal literacies that the students originally exercised when they spoke, read, listened to, and wrote about music with their friends and families. In their daily exchanges, the teenage cultures and identities that these students had built around music channelled themselves through specific literacies, hence the need for Clàudia to make sure that - in accordance with our model of culturally sustaining pedagogy - her proposal harnessed and transferred these informal literacies to the English language classroom in order for the museum project to tap into the motivational aspects that inhered in this fund of identity. A key aspect of these teenage cultures and literacies was that they were necessarily multimodal, i.e., that they relied on and intertwined with images, sounds, multiple artefacts, and multimodal consumer goods. This was the reason why the multimodal quality of museum pedagogies was so suitable in this case, since the project welcomed from the outset original artefacts such as compact discs, concert tickets, photographs from favourite bands, and so on. The pedagogical and multicultural affordances of these teenage literacies would not have been as salient had the project restricted itself to the printed page. For music to motivate and educate these students, all of them had to have the chance to express themselves, to share their own cultures through their own informal literacies. Multimodality was 


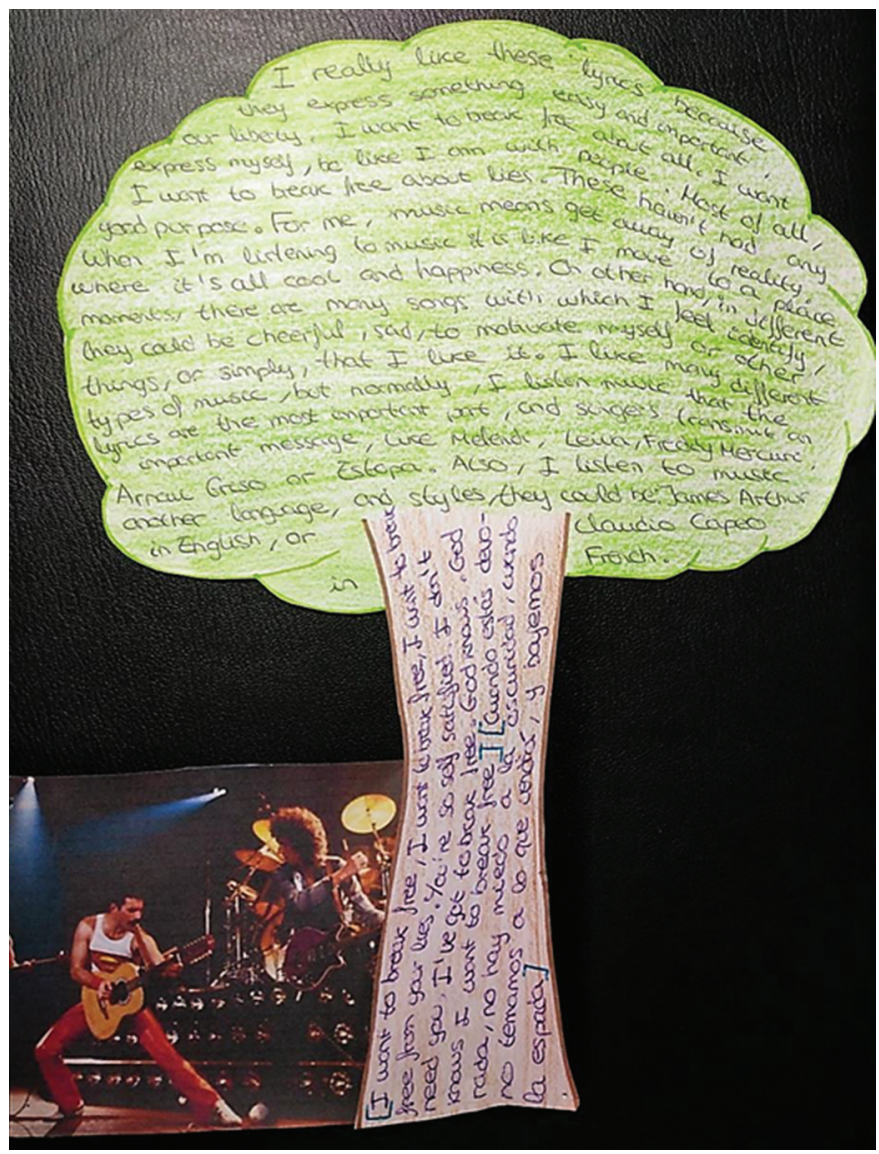

Figure 6. Multimodal text about 'I want to break free' lyrics by Queen.

instrumental to this aim. During her interview, Fiona - a student who 'was not good at English,' in her own words - underlined the originality of the project, not only in terms of the cultural content (music) but especially because it had 'allowed us to express better through means we like' (Fiona, Student Questionnaire, 28 March 2018). Since students' lives were multimodal, their vital interests and youth cultures could only be channelled through multimodality, not through the printed course book. Having written that a CD reminded her of a TV series in which the singer also played a role of leading actor, María's text said that 'the CD [was] made in 2008 and my sister gave it to me as a present for my birthday', as can be read in Figure 7. 'I love doing this kind of things,' María added at the end of the project, 'and I hope we continue doing them instead of learning with a book in front of us' (Maria, Student questionnaire, 28 March 2018).

\section{'Words matter/palabras reales': museum education and community}

The third museum project took place in a public elementary school in Nazaret, one of the most impoverished and multicultural neighbourhoods in València. Even more clearly than in the previous vignette, this urban school showed that English education is socially, 


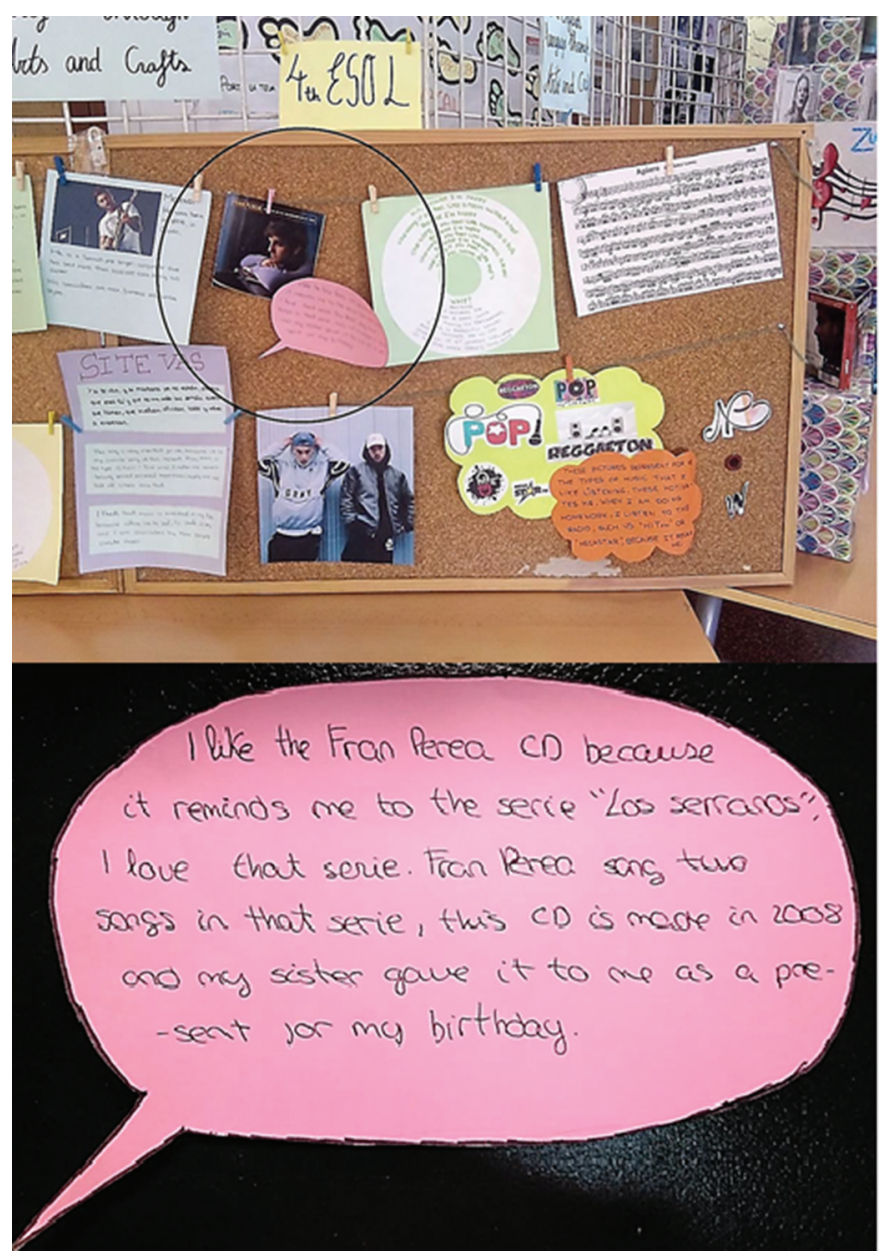

Figure 7. Group exhibit and detail from multimodal text.

economically, and culturally qualified in intense ways. Life in this neighbourhood bears witness to how intense socio-economic stratification deriving from neoliberal policies could end up making the lives of more and more people develop at the margins of, or remain external to, many of the advances taking place in the spheres of cultural, scientific, and economic production (Ajuntament de València 2017; Cucó i Giner 2016), and hence also external to the English language, through which these advances are mostly conveyed. Indeed, the lives of the children in this public school in Nazaret barely intersected with the English language. Their precarious position in neoliberal society expressed itself not only economically, but also culturally and existentially (and linguistically), as life projects strongly anchored to Nazaret's local reality, in which English plays no essential role (Villacañas de Castro, Bodi Cano, and Hortelano Montejano 2018). In order to bridge this gap, Luis designed an extra-curricular project called 'Palabras Reales/Words Matter' with 10 children aged ten to twelve. Their ethnic background was representative of this multicultural school, in which the Spanish Roma student majority cohabited (not without occasional tensions) with children of Romanian, Nigerian, Latin American, North African, and Pakistani origin. 
Luis trusted the above mentioned model of culturally sustainable, museum-oriented pedagogy to expand the material, artifactual, and multimodal resources that were available in the English classroom to allow the students, in turn, to reproduce the literacy practices they developed at home and build on them in the English classroom. During the student interviews, Luis discovered that the children's home literacies were mixed - in the sense that they did not just write and read, but wrote and drew, read and played - and accordingly multimodal, for the texts they wrote were often accompanied by stickers or drawings of themselves or their friends, of their toys, characters from books, TV series, etc. Also, as opposed to the previous two vignettes, the project was overtly multilingual on account of Nazaret's linguistic ecology and the learners' repertoires. Attached to a diversity of materials and artefacts that ranged from multi-sized, multi-coloured cardboards to different kinds of fabrics, colours, stickers, paints, glitter, and photographs, Luis expected that the children's cultures, languages, and literacies (as well as the skills associated with them) would come on board and manifest themselves in the English classroom.

Together with student-teachers from the Primary English Education programme at the University of València, Luis designed two workshops in which these ten children created multilingual, multimodal, artifactual outcomes that could be shared through a community museum held at the public library of Nazaret. The first workshop was called 'Stuff I'm made of' and ran from 17 November 2017 to 9 March 2018. Figure 8 shows how the students used text and images to create multimodal and bilingual self-portraits and then wrote longer, bilingual texts to explain which materials they had used to represent who

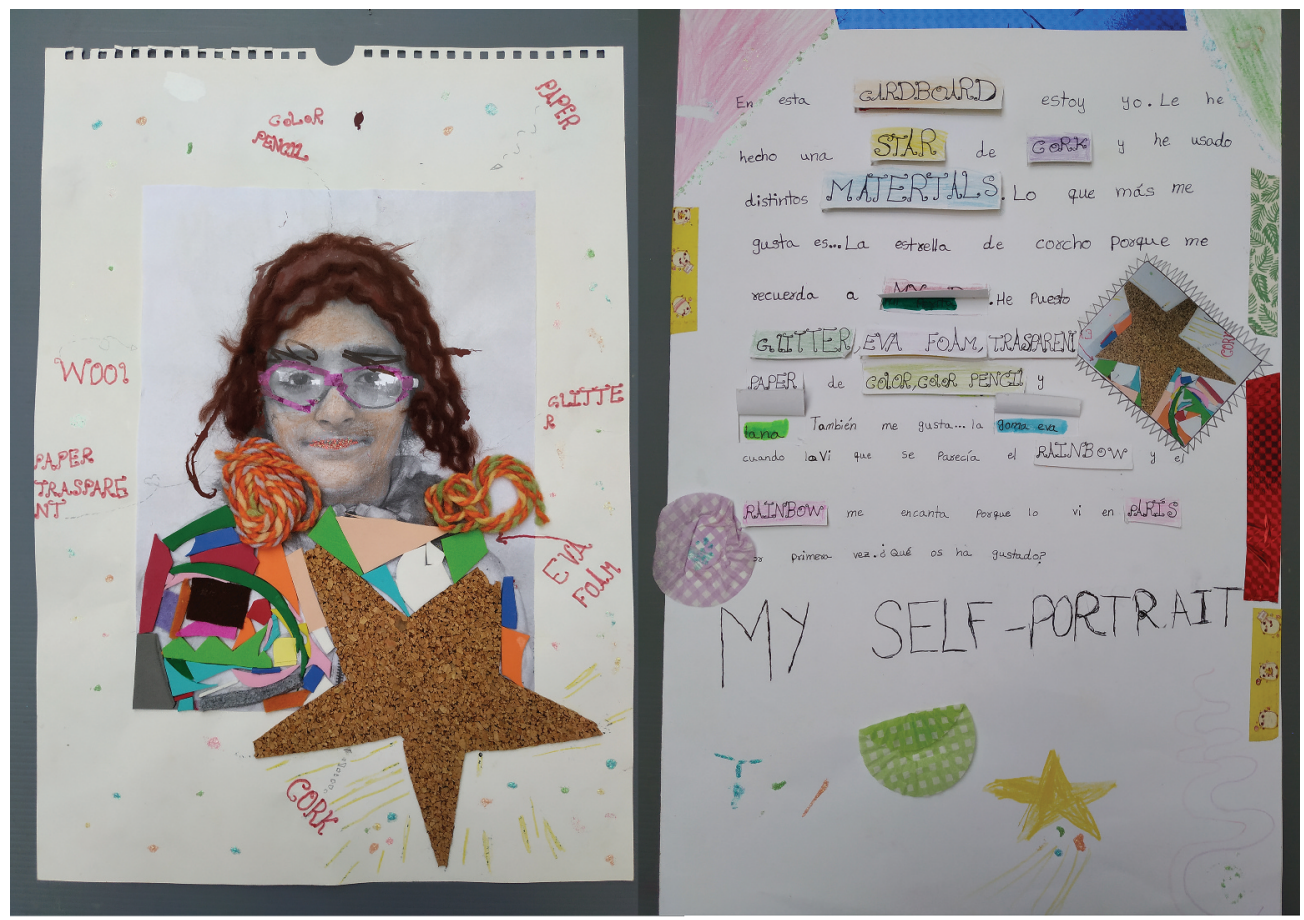

Figure 8. 'Stuff I'm made of', Yomna's multimodal self-portrait. 
they were. In the second workshop, called 'All the world's a board!', photographs became the medium chosen for the students to turn their personal lives into multimodal, curricular resources. Through disposable cameras, the children took photographs of their school, households, and neighbourhoods to capture the activities they carried out in each of these spaces, which structured their lives. Once these photographs were developed, the students explained (orally and in Spanish) the stories and events behind them, giving the rest of the group a glimpse of their childhood cultures and identities. These cultures and identities were essentially rooted in their families and neighbourhood friends, so they were to a large extent independent from mainstream cultural industry. After sharing these stories, the students identified key nouns and verbs contained in each image and made sure they knew the English words for them. They either wrote the English terms down on sticky notes next to each photograph, or played a matching game with the photographs and the words on post-its. Next, with a dossier specifically prepared to scaffold the task, the children wrote sentences in English summarising the activities depicted in their favourite photographs. As seen in Figure 9, the artefact that resulted from all of these phases was a large, wooden board where the students displayed a selection of photographs from their Neighbourhood, Home, and School hubs, whose corresponding labels helped them to structure the multimodal content across the board. Key vocabulary, action verbs, and the short sentences produced earlier were neatly rewritten and added next to the photographs, and the board was decorated with stickers and drawings. In the final museum, all of these elements were finally connected and

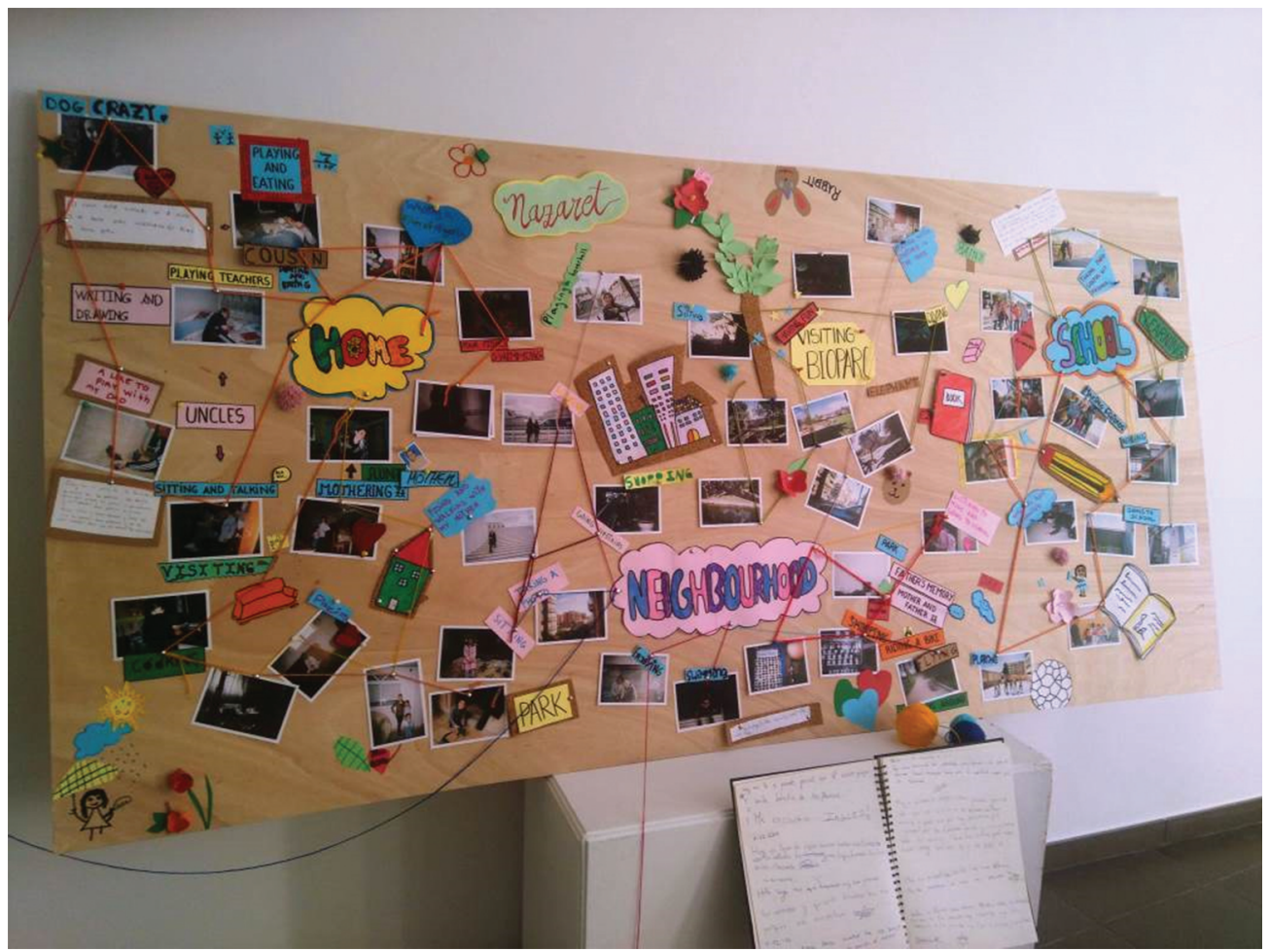

Figure 9. 'All the world's a board!'. 
attached with coloured strings and pins that materialised the socio-material, cultural, and linguistic assemblages that filled the students' lives, giving form to a colourful and complex network.

The successes of the project extended to all the students involved, who experienced an attitudinal and motivational shift in how they related to the English language. These positive effects were best witnessed in Yomna's case, whose work is shown in Figure 8. A sensitive and imaginative girl of barely ten years old, Yomna had already made sense of her mixed ethnic, linguistic, and cultural identities: her father (who, Yomna told us, was working in Paris at that time) came from Pakistan, while her mother was mechera, which is how the Roma community referred to individuals of mixed white and Roma ancestry. By including a wide range of artifactual and material resources, and by offering the students an equally wide range of multimodal forms of expression to channel their voice - drawing, cutting, pasting - the project clearly activated literacy practices that Yomna developed at home. For example, when asked about the similarities between the skills exercised during the workshop and those she normally practiced at home, she pointed to 'painting, mostly. At home I paint with brushes that I've had for a very long time, and paints I got from Paris'. She also kept a journal which she decorated with stickers (Yomna, Student interview, 18 May 2018). As her self-portrait and the interview revealed, through painting Yomna was able to actualise motives and symbols that were central to her own identity and selfconcept, all of which had originated at home and were linked to the healthier aspects of her relationship with her parents:

Luis: So describe to me, for example, the last picture you've drawn at home. What was it about?

Yomna: Mmmm an orange tree. And stars.

Luis: Ok. And why did you draw that picture?

Yomna: I have memories.

Luis: Of what?

Yomna: When I was a child, when my mother taught me how to draw. The first thing she taught me to draw was an orange tree. And stars.

Luis: In the first workshop, what did you include? As far as I remember, there were stars in it, weren't they? I think there were. Yes or no?

Yomna: There was a star. (Yomna, Student interview, 18 May 2018)

Indeed, there was. As shown in Figure 8, her self-portrait had a star in it, made of cork, which she had stuck right at the centre of her image. In the written, bilingual explanation that accompanied her portrait Yomna emphasised that this star was her favourite section (in the following transcription of her text, the words she originally wrote in English appear in italics):

It's me in this cardboard. I have made a star out of cork and I have used different materials. What I like the most is the cork star because it reminds me of my dog [her dog was called Estrella: Star in Spanish]. I have added glitter, EVA foam, transparent color paper, color pencils, and wool. I also like the EVA foam when I saw that it looked like a rainbow and I love the 


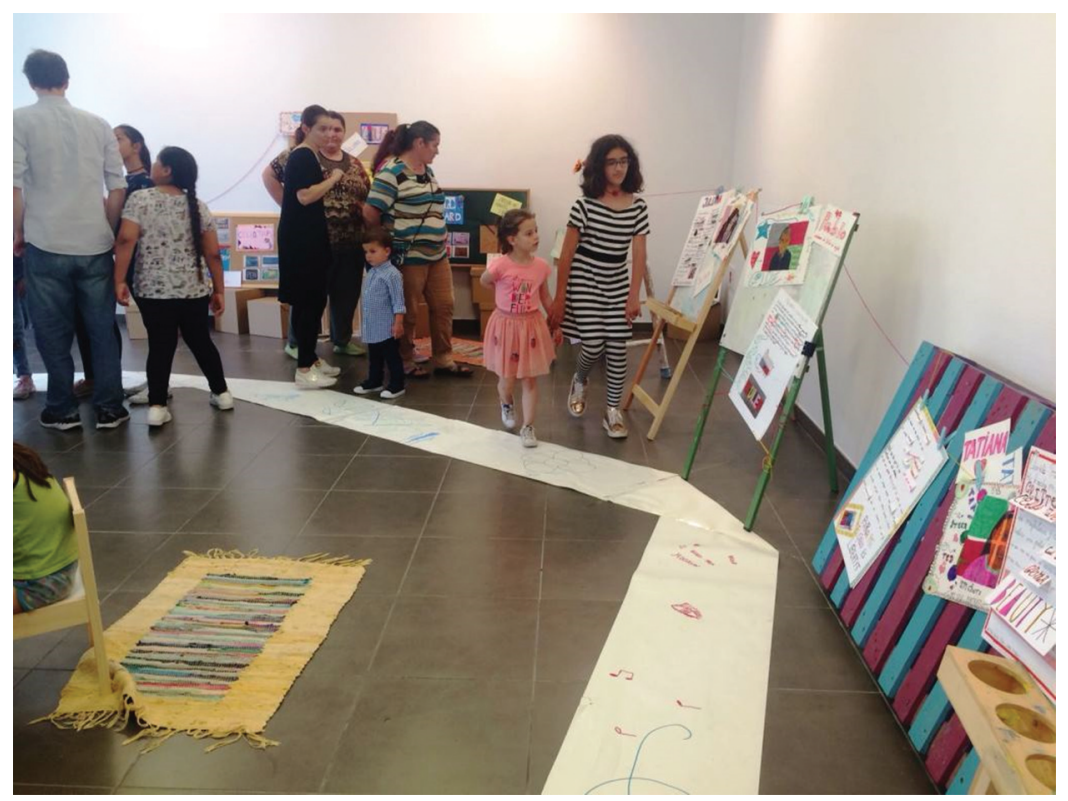

Figure 10. 'Words matter/Palabras reales' exhibition.

rainbow because I saw one in Paris for the first time. (Yomna, 'Stuff I'm made of', multimodal self-portrait)

The interview revealed another reason why Yomna had attached so much importance to the star: 'The star connects with my mother, because she taught me you how to draw, to come up with ideas, to use my imagination ... [...] She told me imagination exists inside you and that you'll never forget it. Even when you grow up' (Yomna, Student interview, 18 May 2018). In fact, it was her mother who had chosen to name their dog Estrella. The star was a nuclear element, a key symbol, an essential fund of identity in which many different childhood experiences and strata of meaning overlapped. Thus, the use of multimodal and artifactual literacies allowed Yomna not only to enact her home literacy practices in the English classroom but also to include vital, key content that she used to create her own identity and give meaning to the world. Personal motives like the city of Paris, her dog, rainbows, the star, or her parents, all of which she had carefully weaved together at home and through her own informal and multimodal literacies, had now formed part of this English project, which became extremely important to her as a result.

Through the community museum organised in the neighbourhood public library, the project brought these cultural, identity, and linguistic processes to full turn, by making the school, family, and community worlds interact within the same physical space. As seen in Figure 10, the students' work could be appreciated not only for their linguistic or academic quality, but as a contribution to Nazaret that respected and enriched their own identities, family cultures, and communities. 'My mother loved the star,' Yomna said. 'I knew she was going to like it' (Yomna, Focus group with students, 25 May 2018). This was no surprise. Figure 10 shows Yomna, in black and white, confidently ushering her family across the exhibition, through her self-portrait and up to where the big board stood. 


\section{Discussion and conclusion}

The previous section's three vignettes illustrate how the members of the collaborative action research project were inspired by basic tenets of museum education. These tenets became key pedagogical resources in the team's development of a model of culturally sustaining pedagogy for the English classroom, a model which allowed them to educate across contexts that greatly differed in terms of learners' cultural backgrounds, socioeconomic status, age, and English language abilities. In each of the three vignettes, museum education maximised the pedagogical affordances of multiculturalism, multimodality, multiliteracy, and multilingualism in their English classrooms and helped their students move through all four phases illustrated in Figure 1. With learners who had included English as part of their middle-class lives (like those who participated in the 'Natural Disasters Museum'), museum pedagogy allowed them to enrich their learning identities and experiences as they socialised and shared their school work in English and made it immediately significant. Conversely, in those cases in which English was barely present in the students' real and imagined worlds (as occurred with the learners involved in the 'Music and Identity Museum' and - especially - in the 'Words Matter/Palabras Reales' project), the use of museum pedagogy transformed English language teaching from the onset. First, through multimodality, the learners' multimodal lives became part of the English classroom; and second, through the museum, it was English that became (if only for a couple of hours) part of their social and cultural lives.

By the end of the research project, Luis, Laura, and Clàudia concluded that at the same time as museum education had raised important challenges, it had also provided them with the tools and resources they needed to overcome them. In other words, while museum-oriented pedagogy demanded work that was worthwhile enough for the English learners and teachers to see the point in sharing it through a display (and it was hard to obtain this kind of work in the English classroom), school museums were also able to bring out the best skills and talents from students and teachers. On the one hand, school museums encouraged English learners to draw on their lives, cultures, identities, literacies, and languages to produce outcomes that were treasured and dear to them. On the other, museum pedagogy gave teachers plenty of ideas and models to organise this vital, multimodal wealth in significant and beautiful ways.

While neither Luis, Laura, or Clàudia are likely to become museum educators in the future, these findings suggest that museums are potential beneficiaries of the model of culturally sustaining pedagogy that was successfully applied in three school contexts. In accordance with the spiralling progress of action research, Luis expects to enrich the multimodal quality of school museums in future cycles of inquiry, this time through audiovisual media that helps the students document the process of the exhibition's becoming, thus embracing a participatory approach to research that also holds promise. Indeed, enriched by insights from museum education, the culturally sustaining pedagogical model explored in this research was capable of organising meaningful educational activities in very diverse ELT classrooms, through three corresponding projects geared to student growth. In accordance with Dewey's (1915) original expectation that museums and schools strengthen their collaboration and dialogue, but also inspired by the hopes expressed in the recent literature by museum educators and researchers, this culturally sustaining pedagogical model seeks to advance towards a scenery in which the 
educational transfers between schools and museums become positive, constant, and reciprocal. The model involved a complex and sophisticated reading of culture, one which exposed the intricate relationship between literacy, modality, language and culture, and hence one which may be useful for any educational institution (museum or otherwise) that wishes to develop on a culturally sustaining plane.

\section{Acknowledgments}

The authors wish to thank the students, families, and teachers of the schools where this research was set for sharing such an enriching educational experience and for giving the authors permission to reproduce the students' names, images, and words, and also examples of their work. Finally the authors thank the editor and anonymous reviewers of Pedagogy, Culture, and Society for the improvements they initiated and sustained through their feedback.

\section{Disclosure statement}

No potential conflict of interest was reported by the authors.

\section{Funding}

This research was funded by the Spanish Ministry of Economy, Industry and Competitiveness, under grant no. HAR2017-85230-R, and by the University of Valencia, under grant no. UV-SFPIE_PID191094156.

\section{ORCID}

Luis S. Villacañas de Castro (iD) http://orcid.org/0000-0002-4121-254X

Laura M. Moreno-Serrano (D) http://orcid.org/0000-0002-8038-423X

\section{References}

Ajuntament de València. 2017. Estudio del Barrio de Nazaret [Report on Nazaret Neighborhood]. València, Spain: Author.

Alim, H. S., and D. Paris. 2017. "What Is Culturally Sustaining Pedagogy and Why Does It Matter?" In Culturally Sustaining Pedagogies. Teaching and Learning for Justice in a Changing World, edited by D. Paris and H. S. Alim, 1-24. New York: Teachers College Press.

Ansbacher, T. 1998. "John Dewey's Experience and Education: Lessons for Museums." Curator 41 (1): 36-49. doi:10.1111/j.2151-6952.1998.tb00812.x.

Banegas, D., A. Pavese, A. Velázquez, and S. M. Vélez. 2013. "Teacher Professional Development through Collaborative Action Research: Impact on Foreign English-language Teaching and Learning." Educational Action Research 21 (2): 185-201.

Block, D. 2012. "Class and SLA: Making Connections." Language Teaching Research 16 (2): 188-205.

Burke, A., and S. Hardware. 2015. "Honoring ESL Students' Lived Experiences in School Learning with Multiliteracies Pedagogy." Language, Culture and Curriculum 28 (2): 143-157.

Burns, A. 2005. "Action Research: An Evolving Paradigm?" Language Teaching 38: 57-74. doi:10.1017/S0261444805002661.

Christensen-Scheel, B. 2017. "An Art Museum in the Interest of Publicness: A Discussion of Educational Strategies at Tate Exchange." International Journal of Lifelong Education 37 (1): 1-17. 
Costantino, T. 2004. "Training Aesthetic Perception: John Dewey on the Educational Role of Art Museums." Educational Theory 54 (4): 398-417.

Cucó i Giner, J. 2016. "A Marginalized Neighbourhood Is Not A Marginal Neighbourhood: Case Study of Nazaret (València)." Revista de Dialectología y Tradiciones Populares 71 (1): 151-171.

Cummins, J., and M. Early. 2010. Identity Texts: The Collaborative Creation of Power in Multilingual Schools. Stoke-on-Trent: Trentham Books.

Davidson, B., C. L. Heald, and G. E. Hein. 2008. "Increased Exhibit Accessibility through Multisensory Interaction." In The Educational Role of the Museum, edited by E. Hooper-Greenhill, 223-238. London: Routledge.

Delpit, L. 2006. Other People's Children: Cultural Conflict in the Classroom. 2nd ed. New York: New Press.

Dewey, J. 1915. The School and Society. Chicago: University of Chicago Press.

Early, M., M. Kendrick, and D. Potts. 2015. "Multimodality: Out from the Margins of English Language Teaching." TESOL Quarterly 49 (3): 447-460.

Eisner, E. W., and S. M. Dobbs. 1986. The Uncertain Profession: Observations on the State of Museum Education in Twenty American Art Museums. A Report to the J. Paul Getty Center for Education in the Arts. Santa Monica, CA: J. Paul Getty Trust.

Eisner, E. W., and S. M. Dobbs. 1988. "Silent Pedagogy: How Museums Help Visitors Experience Exhibitions." Art Education 41 (4): 6-15. doi:10.2307/3193116.

Esteban-Guitart, M., and M. Llopart. 2019. "The Creation and Educational Usage of Identity Artifacts." Profesorado: Revista De Currículum Y Formación Del Profesorado 23: 321-334. doi:10.30827/profesorado.v23i2.9687.

García-Sampedro, M. 2019. "'Five Senses in the Museum': Una Experiencia Multidisciplinar en la Formación del Profesorado Bilingüe (Español-inglés) ['five Senses in the Museum': A Multidisciplinary Experience in Bilingual Teacher Education (Spanish-english)]." Didacticae 5: 145-159. doi:10.1344/did.2019.5.145-159.

Gee, J. P. 2014. Literacy and Education. New York: Routledge.

Giampapa, F. 2010. "Multiliteracies, Pedagogy and Identities: Teacher and Student Voices from a Toronto Elementary School." Canadian Journal of Education 332: 407-431.

Gobert, M. 2018. "Flash Cards, Realia, and Objects." In The TESOL Encyclopedia of English Language Teaching, edited by J. I. Liontas and M. Delli Carpini. doi:10.1002/9781118784235.eelt0188.

Graves, K. 2008. "The Language Curriculum: A Social Contextual Perspective." Language Teaching 41 (2): 147-181.

Hein, G. E. 2004. “John Dewey and Museum Education." Curator 47 (4): 413-427. doi:10.1111/j.21516952.2004.tb00136.x

Hein, G. E. 2011. "Museum Education." In A Companion to Museum Studies, edited by S. Macdonald, 340-352. West Sussex, UK: John Wiley and Sons.

Hooper-Greenhill, E. 1999. "Education, Communication and Interpretation: Towards a Critical Pedagogy in Museums." In The Educational Role of the Museum. Second ed., edited by E. HooperGreenhill, 3-27. London: Routledge.

Hooper-Greenhill, E. 2007. Museums and education: Purpose, Pedagogy, Performance. London: Routledge. doi:10.4324/9780203937525

Huerta, R. 2010. Maestros y Museos. Educar Desde la Invisibilidad [Teachers and Museums. Educating from Invisibility]. València: Universitat de València.

Jarmy, C. 2019. "'Neath the Moth-eaten Rag: Do Artifacts Play a Special Role for Historical Knowledge?" Journal of Philosophy of Education 53 (2): 425-439.

Kanno, Y. 2014. "Forum Commentary." Journal of Language, Identity and Education 13: 118-123. doi:10.1080/15348458.2014.901825.

Kennedy, L. M., R. L. Oviatt, and P. I. De Costa. 2019. “Refugee Youth's Identity Expressions and Multimodal Literacy Practices in a Third Space." Journal of Research in Childhood Education 33 (1): 56-70.

Kristinsdóttir, A. 2017. "Towards Sustainable Museum Education Practices: Confronting Challenges and Uncertainties." Museum Management and Curatorship 32 (5): 424-439.

Martin, J., \& Jennings, M. (2015). Tomorrow's Museum: Multilingual Audiences and the Learning Institution. Museums \& Social Issues, 10(1),83-94. doi: 10.1179/1559689314Z.00000000034 
Moirano, M. C. 2012. "Teaching the Students and Not the Book: Addressing the Problem of Culture Teaching in EFL in Argentina." Gist Education and Learning Research Journal 6: 71-96.

Pahl, K., and A. Pollard. 2010. "The Case of the Disappearing Object: Narratives and Artifacts in Homes and a Museum Exhibition from Pakistani Heritage Families in South Yorkshiore." Museum and Society 8 (1): 1-17.

Pahl, K., and J. Rowsell. 2010. Artifactual Literacies: Every Object Tells a Story. New York, NY: Teachers College Press.

Pahl, K., and J. Rowsell. 2012. Literacy and Education. Second Edition. London: SAGE.

Paris, D., and H. S. Alim. 2014. "What are We Seeking to Sustain through Culturally Sustaining Pedagogy? A Loving Critique Forward." Harvard Educational Review 84 (1): 85-100.

Porto, M. 2010. “Culturally Responsive L2 Education." An Awareness-raising Proposal. ELT Journal 64: 1. doi:10.1093/elt/ccp021.

Sayer, P. 2019. "The Hidden Curriculum of Work in English Language Education: Neoliberalism and Early English Programs in Public Schooling." AlLA Review 32 (1): 36-63.

Stenhouse, L. (1975). An introduction to curriculum research and development. London: Heinemann.

Stojanovic, D. 2017. "Educational Turn in Art: Turning Art into the Production of a New Knowledge." Zbornik Akademije Umetnosti 5: 56-64. doi:10.5937/ZbAkUm1705056S.

Street, B. 2012. "New Literacy Studies." In Language, Ethnography, and Education. Bridging New Literacy Studies and Bourdieu, edited by M. Grenfell, D. Bloome, C. Hardy, K. Pahl, J. Rowsell, and B. Street, 27-49. New York: Routledge.

Thiel, J. 2015. "Vibrant Matter: The Intra-active Role of Objects in the Construction of Young Children Literacies." Literacy Research: Theory, Method, and Practice 64 (1): 112-131.

Vandrick, S. 2014. "The Role of Social Class in English Language Education." Journal of Language, Identity, and Education 13: 85-91. doi:10.1080/15348458.2014.901819

Villacañas de Castro, L. S., V. Cano Bodi, and A. Hortelano Montejano. 2018. "Teaching English as a Non-Imperial Language in an Underprivileged Public School in Spain." TESOL Quarterly 52 (4): 943-970.

Villacañas de Castro, L. S., V. C anoBodi, A. Hortelano Montejano, C. Giner Real, I. Gómez Pons, B. Mesas Tomás, C. Sanz Martínez, and C. Tortosa Gozálvez. 2020. "Matter, Literacy, and English Language Teaching in an Underprivileged School in Spain." TESOL Quarterly doi:10.1002/ tesq.572.

Williams, K. 2019. "The Place of Language Learning in a Liberal Education: Implications for Curriculum Policy in Ireland." Irish Educational Studies 38 (2): 141-156.

Williams, K. 2020. "Work, Play and Language Learning: Some Implications for Curriculum Policy of Michael Oakeshott's Philosophy of Education." Educational Philosophy and Theory 52 (5): 535-548.

Wilson, A. 2004. "Four Days and a Breakfast: Time, Space and Literacy/ies in the Prison Community." In Spatializing Literacy Research and Practice, edited by K. Leander and M. Sheeny, 67-90. New York: Peter Lang.

Yun, S. 2018. "Curiosity, Wonder and Museum Education." Journal of Philosophy of Education 52 (3): 465-482. 